\title{
Pristinochterus gen. n. (Hemiptera: Ochteridae) from the Upper Mesozoic of northeastern China
}

\author{
YunZHI $\mathrm{YAO}^{1}$, WANZHI CAI ${ }^{1,2 *}$ and DONG REN ${ }^{2 *}$ \\ ${ }^{1}$ Department of Entomology, China Agricultural University, Yuanmingyuan West Road, Beijing 100094, China; \\ e-mail: caiwz@cau.edu.cn \\ ${ }^{2}$ Key Lab of Insect Evolution \& Environmental Changes, Capital Normal University, Beijing 100037, China; \\ e-mail: rendong@mail.cnu.edu.cn
}

Key words. Heteroptera, Ochteroidea, Ochteridae, Pristinochterus, Upper Mesozoic, fossil, Yixian Formation, Jiufotang Formation, China

\begin{abstract}
A new genus of velvety shore bugs, Pristinochterus gen. n., with one new species, Pristinochterus zhangi sp. n., are described. The specimens were collected from the Late Jurassic to Early Cretaceous Yixian Formation and Early Cretaceous Jiufotang Formation in northeastern China. This finding represents the first record of fossil velvety shore bugs from China. Among the specimens, four well-preserved nymphs are reported for the first time. The placement of the new genus within Ochteridae is briefly discussed. A key to the world genera of Ochteridae is provided.
\end{abstract}

\section{INTRODUCTION}

The extant Ochteridae is a small family with three genera and 55 species, distributed in the tropical and warm-temperate regions of the world (Baehr, 1989a; Schuh \& Slater, 1995). These bugs are usually found along the shores of ponds or streams. They look like Saldidae, and feed on soil microfauna of the littoral zone (Shcherbakov \& Popov, 2002). Only one species, Ochterus marginatus (Latreille), is recorded from China (Zheng, 1999). Records of fossil ochterids are scarce and only one species, Propreocoris maculatus Popov, Dolling \& Whalley 1994, from the Early Jurassic (Lower Lias) Charmouth fauna in England has been reported. Recently we discovered 19 fossil specimens, including four parts and counterparts, of velvety shore bugs collected from the Yixian Formation in Huangbanjigou, Chaomidian Village, Beipiao City and Dawangzhangzi Village, Lingyuan City, Liaoning Province and Jiufotang Formation in Balihan Village, Ningcheng County, Chifeng City, Inner Mongolia Autonomous Region, China. As they can not be assigned into any known genera of Ochteridae, we erect a new genus to receive them.

Jiufotang Formation and Yixian Formation are considered as part of the Jehol Biota, yielding not only wellpreserved primordial birds, pterosaurs, lizards and angiosperms, but also many beautifully preserved insects (Sun et al., 1998; Hou et al., 1999; Ren et al., 2002; Ren et al., 2003; Wang \& Zhou, 2003; Wang, 2004). The age of the Jiufotang Formation is Lower Cretaceous (Tao et al., 2003; Liu et al., 2004). The Yixian Formation locates below Jiufotang Formation, its age remains contentious. There are three opinions about its age: Late Jurassic (Ren et al., 1997; Zheng et al., 2003), transition from Late
Jurassic to Early Cretaceous (Chen et al., 2004; Wang et al., 2004, 2005), and Early Cretaceous (Swisher et al., 1999; Li et al., 2001; Pang et al., 2002; Zhou et al., 2003). Here, we tentatively consider the geological age of the Yixian Formation as the transition from Late Jurassic to Early Cretaceous (Late Tithonian to the Berriasian).

\section{MATERIAL AND METHODS}

The material studied is deposited at the Key Lab of Insect Evolution \& Environmental Changes, Capital Normal University, Beijing. All drawings were made using a camera lucida and binocular microscope. Morphological terminology in this paper mainly follows Baehr (1989b). All measurements are in millimeters.

\section{SYSTEMATICS}

Suborder Heteroptera Latreille, 1810

Infraorder Nepomorpha Popov, 1968

Superfamily Ochteroidea Kirkaldy, 1906

Family Ochteridae Kirkaldy, 1906

Genus Pristinochterus gen. $n$.

Type species. Pristinochterus zhangi sp. $\mathrm{n}$.

Diagnosis. Adults: Body medium sized, broad and ovoid, about twice as long as width. Head subquadrate, shorter than width across eyes, anterior margin strongly expanded, foliate-like, apex round, anteocular portion distinctly longer than diameter of eye in dorsal view; antennae arising from near middle of head, 4-segmented, short, visible dorsally, basal two segments slender, apical two segments stouter, all segments subequal in length; eyes relatively small, shorter than half width of head, round, contiguous to anterior margin of pronotum, projecting over lateral sides of head, interocular space longer

\footnotetext{
* Corresponding authors.
} 
TABLE 1. Similarities and differences among the five genera of Ochteridae.

\begin{tabular}{|c|c|c|c|c|c|}
\hline & Ochterus & Ocyochterus & Megochterus & Pristinochterus & Propreocoris \\
\hline $\begin{array}{l}\text { Body length } \\
(\mathrm{mm})\end{array}$ & less than 6.5 & 5.17 & $8.3-9.8$ & $10-12.9$ & $\begin{array}{l}5.4 \text { (excluding } \\
\text { head) }\end{array}$ \\
\hline Dorsum of body & $\begin{array}{l}\text { pronotum scutellum, } \\
\text { clavus and corium } \\
\text { finely punctate }\end{array}$ & $\begin{array}{l}\text { pronotum scutellum, } \\
\text { clavus and corium } \\
\text { finely punctate }\end{array}$ & $\begin{array}{l}\text { pronotum scutellum, } \\
\text { clavus and corium } \\
\text { finely punctate }\end{array}$ & $\begin{array}{l}\text { pronotum scutellum, } \\
\text { clavus and corium } \\
\text { smooth, impunctate }\end{array}$ & $\begin{array}{l}\text { pronotum scutel- } \\
\text { lum, clavus and } \\
\text { corium finely } \\
\text { punctate }\end{array}$ \\
\hline Head & $\begin{array}{l}\text { anterior margin not } \\
\text { expanded; much } \\
\text { shorter than wide }\end{array}$ & $\begin{array}{l}\text { anterior margin not } \\
\text { expanded; much } \\
\text { shorter than wide }\end{array}$ & $\begin{array}{l}\text { anterior margin pro- } \\
\text { longed; much shorter } \\
\text { than wide }\end{array}$ & $\begin{array}{l}\text { anterior margin strongly } \\
\text { expanded, flake-like; } \\
\text { slightly shorter than } \\
\text { wide }\end{array}$ & lacking data \\
\hline Eye & $\begin{array}{l}\text { large, diameter } \\
\text { slightly shorter than } \\
\text { head }\end{array}$ & $\begin{array}{l}\text { large, diameter } \\
\text { slightly shorter than } \\
\text { head }\end{array}$ & $\begin{array}{l}\text { large, diameter sube- } \\
\text { qual to half of head } \\
\text { length }\end{array}$ & $\begin{array}{l}\text { relatively small, } \\
\text { diameter much shorter } \\
\text { than half of head length }\end{array}$ & lacking data \\
\hline Rostrum & $\begin{array}{l}\text { generally extended } \\
\text { beyond hind coxae }\end{array}$ & $\begin{array}{l}\text { reaching base of } \\
\text { abdomen }\end{array}$ & $\begin{array}{l}\text { generally extended } \\
\text { beyond hind coxae }\end{array}$ & reaching to mid coxae & lacking data \\
\hline Antennae & $\begin{array}{l}\text { first } 2 \text { segments } \\
\text { stouter and shorter } \\
\text { than } 2 \text { apical seg- } \\
\text { ments }\end{array}$ & $\begin{array}{l}\text { first } 2 \text { segments } \\
\text { stouter and shorter } \\
\text { than } 2 \text { apical segments }\end{array}$ & $\begin{array}{l}\text { all } 4 \text { segments stout } \\
\text { and subequal in thick- } \\
\text { ness }\end{array}$ & $\begin{array}{l}\text { all } 4 \text { segments subequal } \\
\text { in thickness, } 2 \text { apical } \\
\text { segments stouter than } \\
\text { basal } 2 \text { segments }\end{array}$ & lacking data \\
\hline Pronotum & $\begin{array}{l}\text { with transverse sul- } \\
\text { cus, lateral margins } \\
\text { not expanded }\end{array}$ & $\begin{array}{l}\text { without transverse sul- } \\
\text { cus, lateral margins } \\
\text { expanded }\end{array}$ & $\begin{array}{l}\text { with transverse sulcus, } \\
\text { lateral margins not } \\
\text { expanded }\end{array}$ & $\begin{array}{l}\text { without transverse sul- } \\
\text { cus, lateral margins } \\
\text { strongly expanded }\end{array}$ & $\begin{array}{l}\text { pronotum narrow, } \\
\text { with transverse } \\
\text { sulcus }\end{array}$ \\
\hline Costal fracture & present & present & present & absent & present \\
\hline $\begin{array}{l}\text { Cells on mem- } \\
\text { brane }\end{array}$ & $\begin{array}{l}\text { with } 7 \text { cells in two } \\
\text { rows }\end{array}$ & with $10-12$ cells & with about 20 cells & with about 30 cells & $\begin{array}{l}\text { with } 6 \text { longitu- } \\
\text { dinal veins and } \\
\text { forming some } \\
\text { large cells, } \\
\text { probably less than } \\
7\end{array}$ \\
\hline Tibiae & $\begin{array}{l}\text { with a row of fine } \\
\text { spines ventrally }\end{array}$ & $\begin{array}{l}\text { with a row of fine } \\
\text { spines ventrally }\end{array}$ & $\begin{array}{l}\text { with a row of fine } \\
\text { spines ventrally }\end{array}$ & $\begin{array}{l}\text { spines not forming in } \\
\text { rows }\end{array}$ & lacking data \\
\hline
\end{tabular}

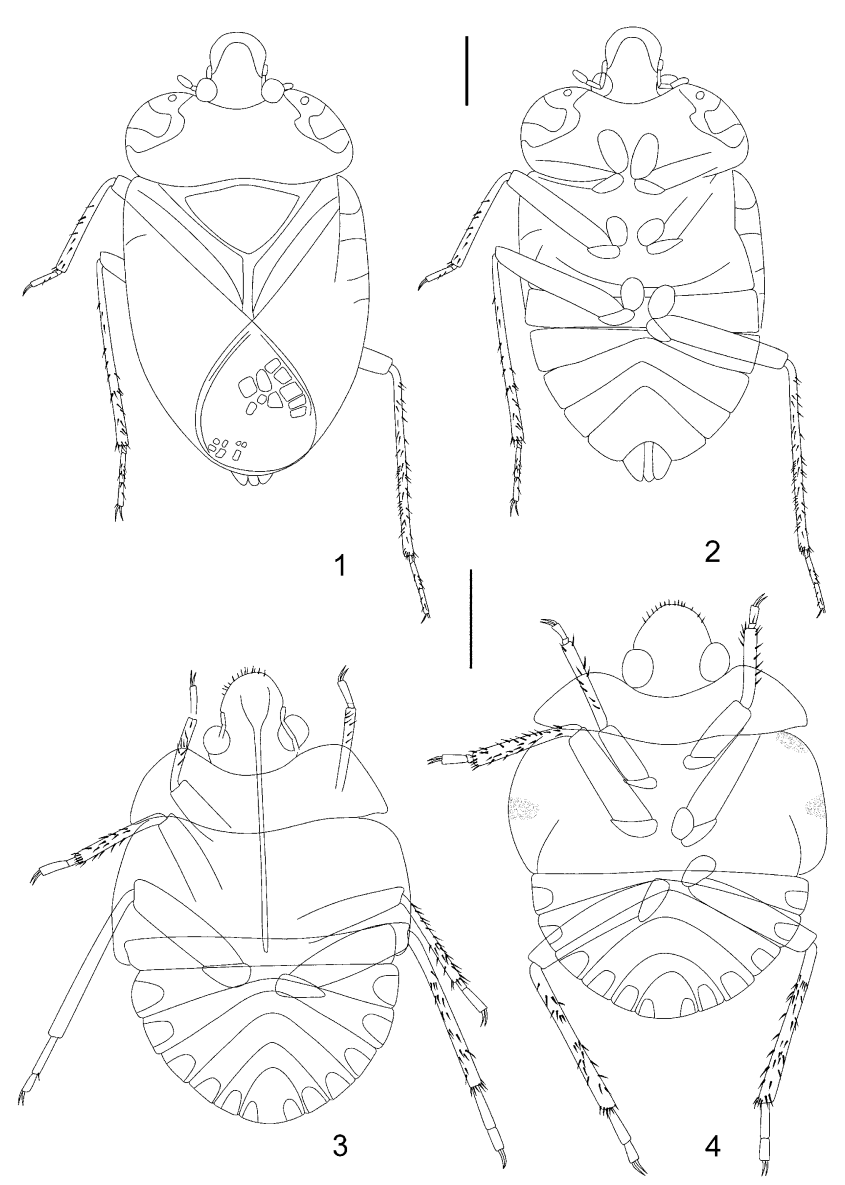

than diameter of eye in dorsal view; rostrum long, extending to hind coxae. Pronotum subquadrate, strongly expanded laterally, shorter than wide, anterior and posterior margins concave, without collar, dorsum smooth, without transverse sulcus, anterior and posterior angles nearly rounded, lateral margin convex. Scutellum as long as pronotum at midline, subtriangular, tip blunt. All legs cursory, fore coxae developed, oblong, narrowly separated, mid and hind coxae less developed, round, all trochanters rounded triangular, fore and hind femora distinctly shorter than corresponding tibiae, mid femur subequal in length to mid tibia, femur distinctly thicker than tibia, tapering, tibiae with setae and stout spines, spines not placed in rows, tarsal 2-2-3, with setae and stout spines, subequal in thickness, basal tarsomeres of all legs short, second tarsomere longest, claws slender and longer than basal tarsomere. Width of body across hemielytra in resting position slightly wider than abdomen, fore wing macropterous, corium-membrane boundary indistinct, corium with deep median fracture, ending at middle of fore wing, without costal fracture, clavus broad, claval commissure subequal to scutellum in length, nearly straight, membrane with about 30 cells. Abdomen oval, with eight visible segments, abdominal sterna IV-VII

Figs 1-4. Pristinochterus zhangi gen. et sp. n., outline. 1, 2. Holotype, $q$ : 1 - CNU-HE-LB2006301, ventral view; 2 CNU-HE-LB2006302, dorsal view; 3, 4. paratype, nymphs: 3 CNU-HE-LB2006316; 4 - CNU-HE-LB2006314. Scale: 2 mm. 


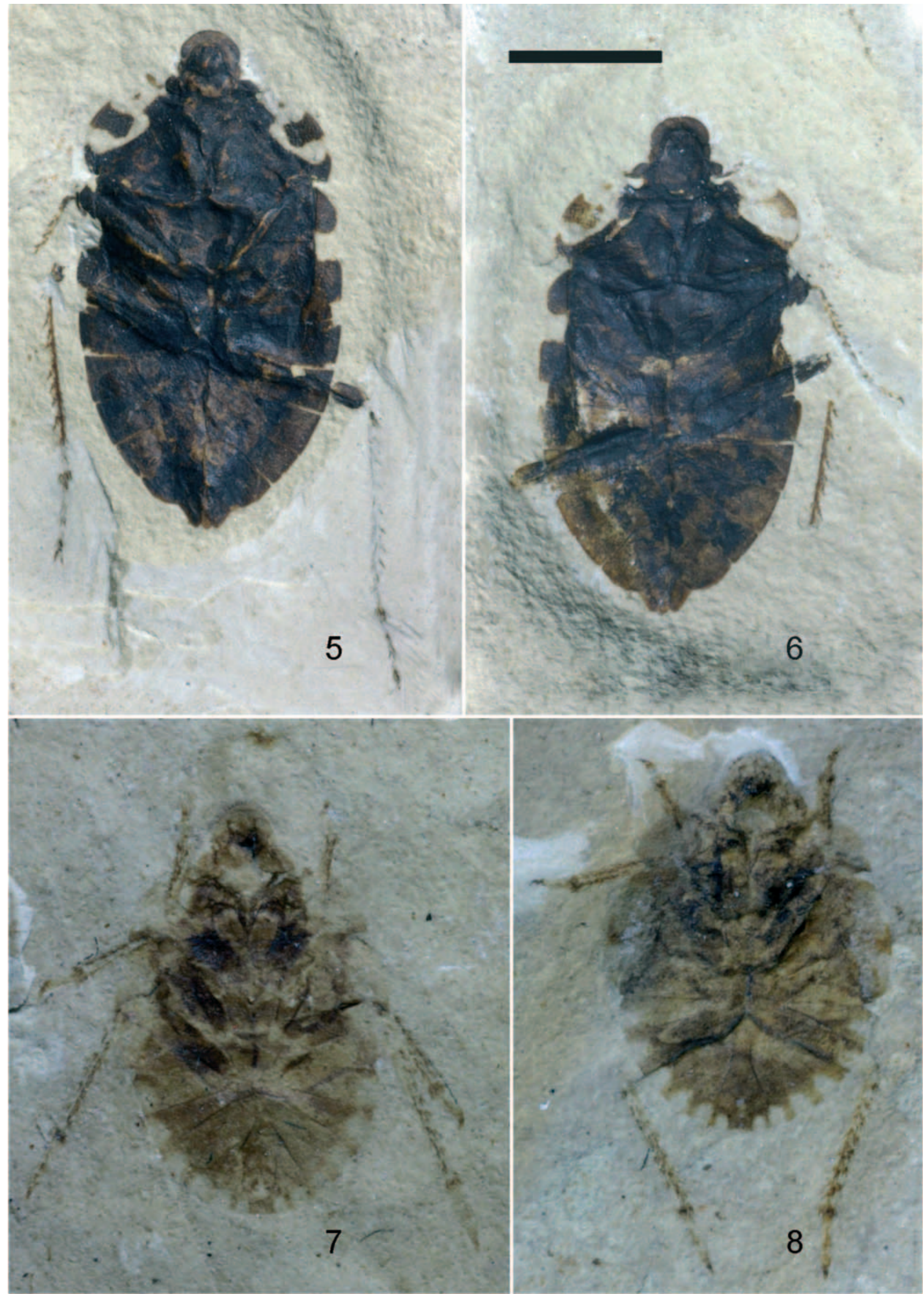

Figs 5-8. Pristinochterus zhangi gen. et sp. n., photograph. 5-6-Holotype, part and counterpart; 7-8 - paratype, nymphs. Scale: $4 \mathrm{~mm}$. 


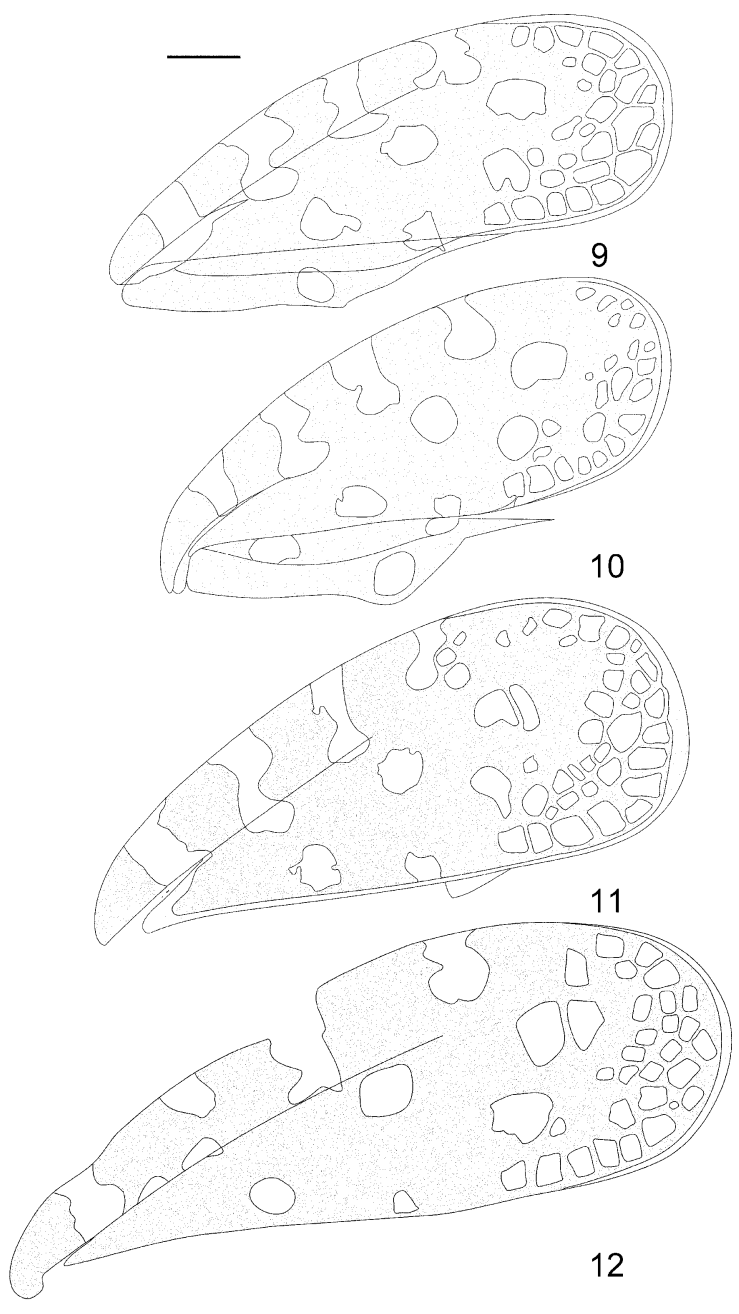

Figs 9-12. Forewing, Pristinochterus zhangi gen. et sp. n., outline. 9 - CNU-HE-LB2006311; 10 - CNU-HE-LL2006006; 11 - CNU-HE-LB2006312; 12 - CNU-HE-NB2006002. Scale: $1 \mathrm{~mm}$.

sinuate; male abdominal sternum VIII split into two independent plates, asymmetrical, ovipositor short, extending through last abdominal segment.

Nymphs (probably fifth instar): Body ovoid, about 1.5 times as long as width. Head length subequal to width, anterior margin with a row of small, erect spines; antennae short, protruding; eyes large, contiguous to anterior margin of pronotum, interocular space longer than diameter of eye in dorsal view; rostrum long, extending to hind coxae. Pronotum shorter than wide, without collar, dorsum smooth, without transverse sulcus, anterior margin concave, posterior margin nearly straight, lateral margins strongly expanded, anterior angles nearly rounded, posterior angles acute. All legs cursory, trochanters rounded triangular, fore and hind femora distinctly shorter than corresponding tibiae, mid femur subequal in length to corresponding tibia, femora distinctly thicker than corresponding tibiae, tapering, tibiae with stout spines, spines shorter than diameter of tibia, tarsus 2-segmented, tarsomeres subequal in thickness, fore tarsi similar to mid tarsi, basal tarsomere short, first tarsomere of hind tarsus longer than second. Abdomen semicircular, with seven visible segments, abdominal sterna IV-VII sinuate.

Remarks. These specimens can be assigned to the family Ochteridae by the following combination of features: antennae 4-segmented, short, placed on the ventral side of eyes, visible dorsally; rostrum extending to hind coxae; all legs cursory, tarsal 2-2-3, basal tarsomeres of all legs short; male abdominal sterna VIII split into two independent plates, asymmetrical. The new genus can be distinguished from the other four genera by the following key. The main similarities and differences among the five genera can be found in Table 1.

Etymology. Genus name is a combination of the Latin pristin (primordial) and Ochterus (the type genus of this family).

\section{Distribution. China.}

\section{Key to genera of Ochteridae}

1 Pronotum considerably narrower than width across forewings; veins on membrane parallel, reaching apical margin of fore wing. . . . . . . . . . . . . . . . . . . . . . . Propreocoris Popov, Dolling \& Whalley, 1994

- Pronotum wider than width across forewings; veins on

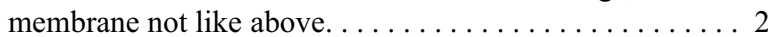

2 Less than 15 cells on membrane.............. 3

More than 15 cells on membrane... . . . . . . . . . . 4

3 Membrane with seven cells in two rows. ............ . . . . . . . . . . . . . . Ochterus Latreille, 1807

- Membrane with 10-12 cells. . . . . . . . . . . . . . . . . . .......... Ocyochterus Drake \& Gómez-Menor, 1954

4 Body large, length ranging $10-14.3 \mathrm{~mm}$; eye relatively small, diameter shorter than half of head width; lateral margins of pronotum strongly expanded; costal fracture absent, membrane with about 30 cells. . . . . Pristinochterus gen. $\mathrm{n}$.

- Body length less than $10 \mathrm{~mm}$; eye large, diameter subequal in length to half of head; lateral margins of pronotum expanded; costal fracture distinct, membrane with about 20 cells. . . . . . . . . . . . . Megochterus Jaczewski, 1934

\section{Pristinochterus zhangi sp. n.}

Description. Color. Pronotum with irregular markings along lateral sides, anterior area with two subquadrate spots, posterior part with 12 light yellow markings, arranged in two rows: five in anterior and seven in posterior row. Hemielytron with 11 light yellow markings: four large at costal margin, three in middle of fore wing, one near claval suture, one at claval suture, one at outer margin of clavus and one at inner angle of clavus. Markings varying in size and shape, but color pattern similar.

Adults (Figs 1, 2, 5, 6, 9-35): Length of body about 1.8 times its width. Head length subequal to that of pronotum at midline, 1.2 times as wide as long; eyes somewhat prominent, about 0.5 times as wide as interocular space; ocelli indistinct. Pronotum 3.2 times as wide as long. Scutellum 1.7 times as wide as long. Femora stout, more than twice as thick as corresponding tibiae, tibiae with dense spines, spines shorter than diameter of tibia; fore tibiae almost 1.4 times as long as corresponding femora, tarsi short, 0.3 times as long as corresponding tibiae; mid tibia slightly shorter than mid femur, tarsi similar to fore tarsi, 0.25 times as long as mid tibiae; hind legs distinctly longer than fore and mid legs, tibiae almost 1.4 times as long as femora, hind tarsi elongated, 0.33 times as long as 

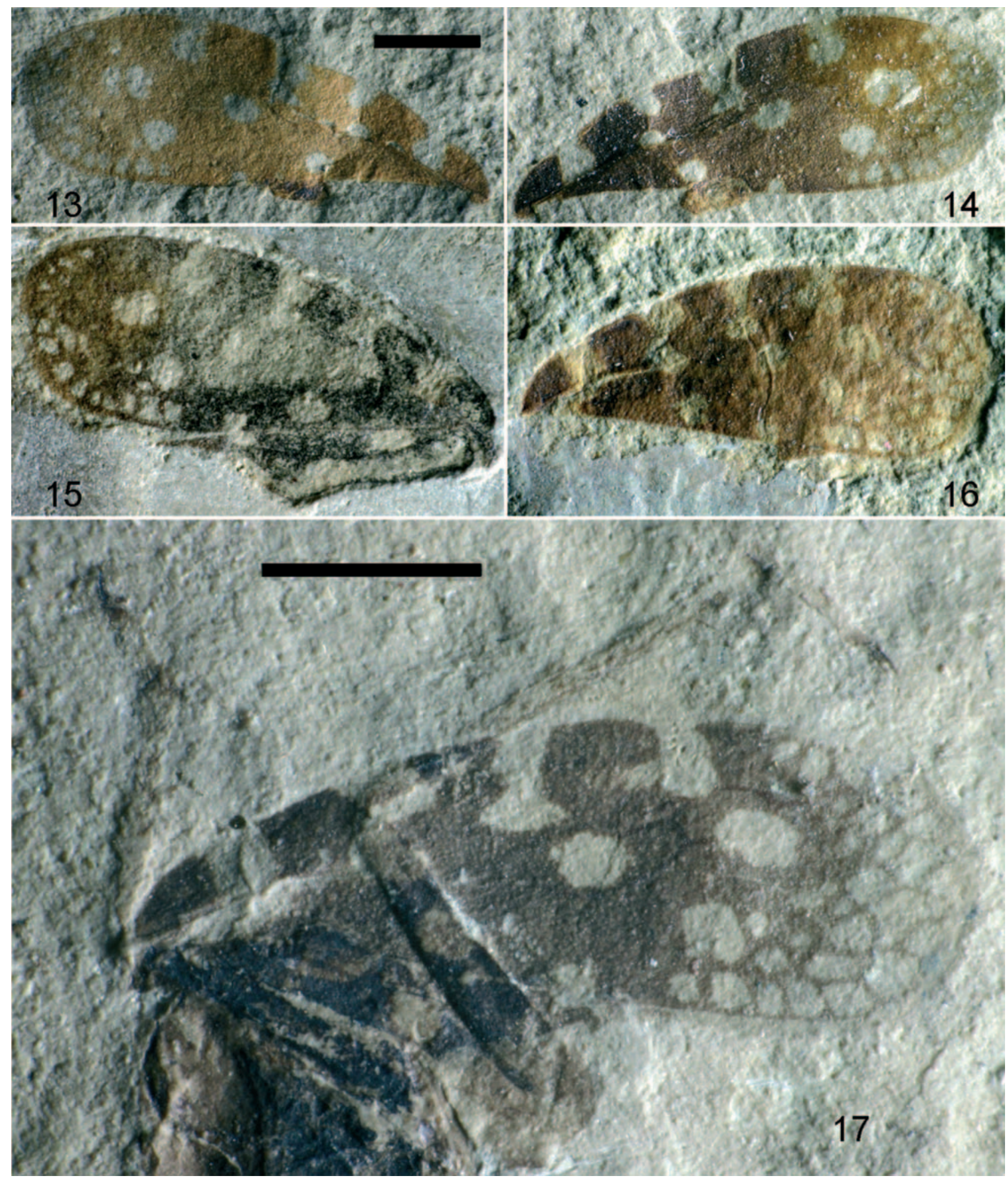

Figs 13-17 Forewing, Pristinochterus zhangi gen. et sp. n., photograph. 13-14 - CNU-HE-NB2006001-002, part and counterpart; 15 - CNU-HE-LL2006006; 16 - CNU-HE-LB2006312; 17 - CNU-HE-LB2006311. Scale: 2 mm.

hind tibiae, second tarsomere longest, 3.7 times as long as first and 1.2 times as long as third tarsomere. Hemielytron reaching tip of abdomen, almost 2.9 times as long as wide, costal margin of hemielytron feebly convex, middle with a deep median fracture, nearly 0.6 times as long as fore wing; clavus wide and large, nearly 4.5 times as long as wide, almost 0.6 times as long as hemielytron.
Nymphs (probably fifth instar, Figs 3, 4, 7, 8): Length of body about 1.4 times its width. Head longer than pronotum at midline, 1.2 times as wide as long; eyes somewhat prominent, about 0.7 times as wide as interocular space. Pronotum 4.6 times as wide as long; femora stout, over twice as thick as corresponding tibiae, tibiae with dense spines, spines shorter than diameter of tibia, fore 

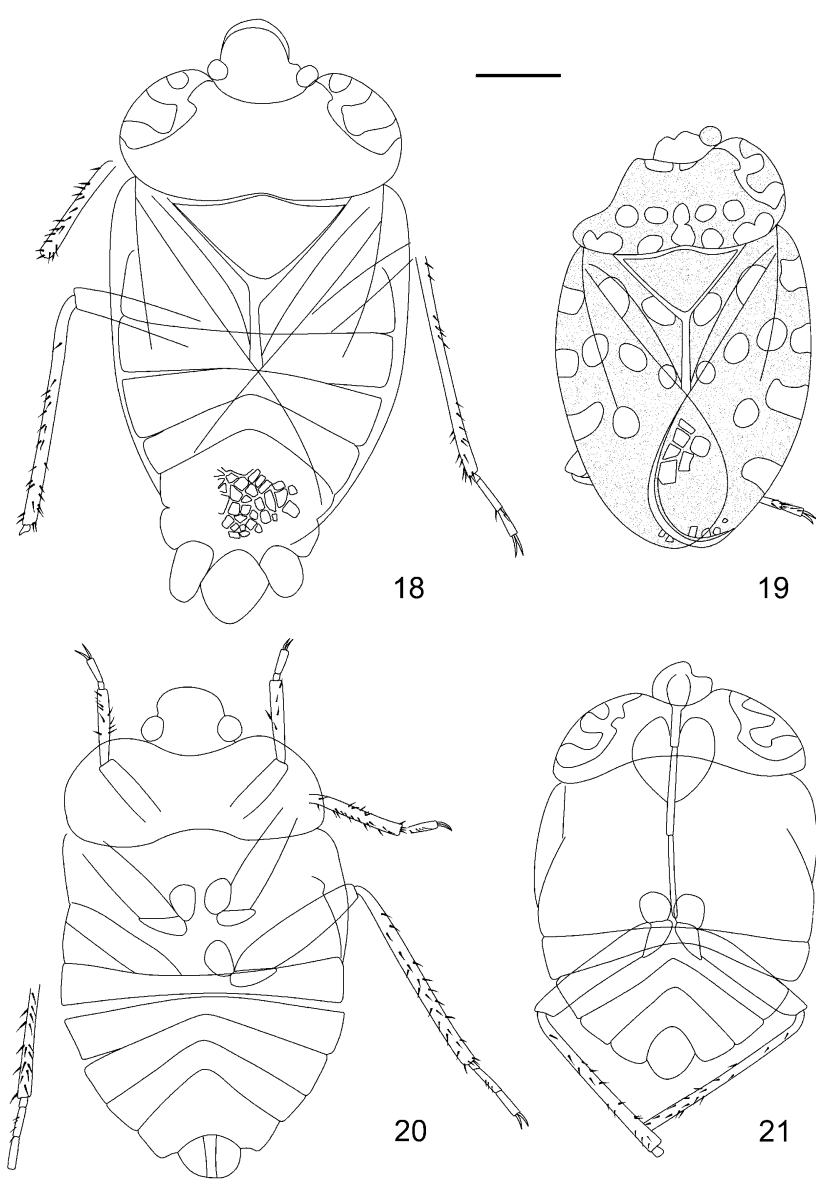

Figs 18-21. Pristinochterus zhangi gen. et sp. n., outline. 18 ๙, CNU-HE-LB2006317; 19 - đo, CNU-HE-LB2006310; 20 -

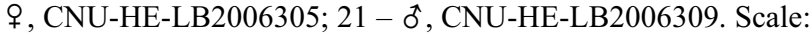
$2 \mathrm{~mm}$.

tibiae almost 1.1 times as long as fore femora, fore tarsi short, almost 0.3 times as long as fore tibiae; mid tibiae subequal in length to mid femora, tarsi similar to fore tarsi, almost 0.3 times as long as mid tibiae; hind legs distinctly longer than fore and mid legs, tibiae almost 1.2 times as long as femora, tarsi elongated, almost 0.37 times as long as tibiae, first tarsomere about twice as long as second tarsomere. Abdomen broad, wider than long, with U-shaped paler markings at lateral sides of each segment.

Dimensions (in mm). Adults. Body length 10-14.3 (ㅎ) (14.3 measured from a squeezed specimen), 11.60-12.90 (ㅇ); maximal width of body 5.88-7.06 (ठ) , 6.59-6.65 (\$); length head 2.00-2.18 (ô), 1.65-2.18 (o), width 2.24-2.59 (ô), 2.35-2.47 (q). Length antennal segments I-V: 0.37, 0.34, 0.39, 0.41 ( + ); length rostral segments I-IV: ?, ?, 2.12, 2.00 (के), total 5.76 (ठ) ; length pronotum 1.82-2.12 (ठ ), 1.76-1.94 (ㅇ), width 5.88-6.65 (ठే), 6.18-6.47 (\$); length scutellum 1.47-2.00 (ठే), 2.00 (\%), width 2.65-4.00 (ठ), 3.24 ( $\%$ ); length hemielytron

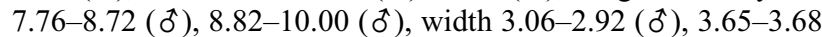
( + ), length clavus $4.18-5.52$ ( $q$ ); length fore leg: femur 1.30 (o), tibia 1.88 (o), tarsomeres I-II: $0.18,0.59$ (ठ), claw 0.35 ; length mid leg: femur 3.08-3.29 (ठิ), 3.12-3.47(o), tibia 2.76

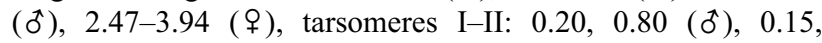
0.71-0.76 (ㅇ), claw: 0.40 (ठ) $), 0.35-0.41$ (); length hind leg: femur 3.12-3.60 (ठే), 3.41-3.82 (o), tibia 4.35-5.29 (ठే), 4.94-5.41(q), tarsomeres I-III: $0.12-0.18, \quad 0.68-0.71$, $0.53-0.56$ (ठ̊) $), 0.21-0.23,0.76-0.82,0.65-0.71$ (ㅇ), claw: $0.41-0.44$ ( (̊)), 0.35-0.47 (ㅇ).

Nymphs (probably fifth instar): Body length 8.23-9.11; maximal width of body 6.00-6.35. Head length 1.82-2.06, width 2.12-2.15; length antennal segments I-V: 0.29, 0.41, ?, ?; length rostrum 5.30. Length pronotum $0.88-1.17$, width 5.18-5.40; length fore leg: femur 1.35, tibia 1.71, tarsomeres I-II: $0.12,0.35$, claw: 0.35 ; length mid leg: femur 2.24, tibia $2.00-2.24$, tarsomeres I-II: $0.12-0.19, \quad 0.47-0.59$, claw: 0.29-0.35; length hind leg: femur 2.35-2.71, tibia 3.24-3.29, tarsomeres I-II: 0.76-0.88, 0.41, claw: 0.35 .

Type materials. Holotype, + , CNU-HE-LB2006301-302 (part and counterpart); paratypes, 9 $\hat{0}$ : CNU-HE-B2006303-304 (part and counterpart), CNU-HE-LB2006305/306/307/308/ 309/310/313/317 (CNU-HE-LB2006306 was donated by Dr. ChungKun Shih); 19: CNU-HE-LB2006305; two specimens, sex unknown: CNU-HE-LB2006012/021; 4 fore wings: CNUHE-LB2006311/312, CNU-HE-NB2006001-002 (part and counterpart), CNU-HE-LL2006006; 4 nymphs: CNU-HELB2006314/315/316.

Locality and horizon. Huangbanjigou, Chaomidian Village, Beipiao City and Dawangzhangzi Village, Lingyuan City, Liaoning Province, Yixian Formation, Late Jurassic; Balihan Village, Ningcheng County, Chifeng City, Inner Mongolia Autonomous Region, China, Jiufotang Formation, Early Cretaceous.

Etymology. This species is named after Mr. Lin Zhang for his assistance and contribution in collecting Liaoning fossils.

ACKNOWLEDGEMENTS. We sincerely thank P. Štys of Charles University, H. Zettel of the Natural History Museum Vienna, and one anonymous reviewer for helpful comments on the manuscript. We sincerely thank C.K. Shih of Capital Normal University, Beijing for his improvement of an earlier draft of the manuscript and M. Liu for practical help. Special thanks are due to E. Guilbert of the Muséum national d'Histoire naturelle for providing some information on the genus Ocyochterus. This research is partly supported by grants from the National Natural Science Foundation of China (Nos. 30370161, 30370184, 30430100), Beijing Natural Science Foundation Program (No. 6042014), the Scientific Research Key Program (KZ200410028013) and PHR Project of Beijing Municipal Commission of Education.

\section{REFERENCES}

BAEHR M. 1989a: Review of the Australian Ochteridae (Insecta, Heteroptera). Spixiana (München) 11: 111-126.

BAEHR M. 1989b: Revision of the genus Ochterus Latreille in the Australian region (Heteroptera: Ochteridae). Entomol. Scand. 20: 449-477.

BAEHR M. 1990: Revision of the genus Megochterus Jaczewski (Insecta: Heteroptera: Ochteridae). Invertebr. Taxon. 4: 197-203.

Chen P.J., Wang Q.F., Zhang H.C., Cao M.Z, Li W.B., Wu S.Q. \& SHEN Y.B. 2004: Discussion on the stratotype of Jianshangou of Yixian Formation. Sci. China (Ser. D) 34: 883-895 [in Chinese, English abstract].

Drake C.J. \& Gómez-Menor J. 1954: A new genus of Ochteridae (Hemiptera). EOS 30: 157-159.

Hou L.H., Martin L.D. \& ZHou Z.H. 1999: A diapsid skull in a new species of the primitive bird Confuciusornis. Nature 399: 679-682.

JACZEWSKI T. 1934: Notes on the Old World species of Ochteridae (Heteroptera). Ann. Mag. Nat. Hist. 10: 597-613.

KIRKALDY G.W. 1906: List of the genera of the pagiopodous Hemiptera-Heteroptera, with their type species, from 1758 to 

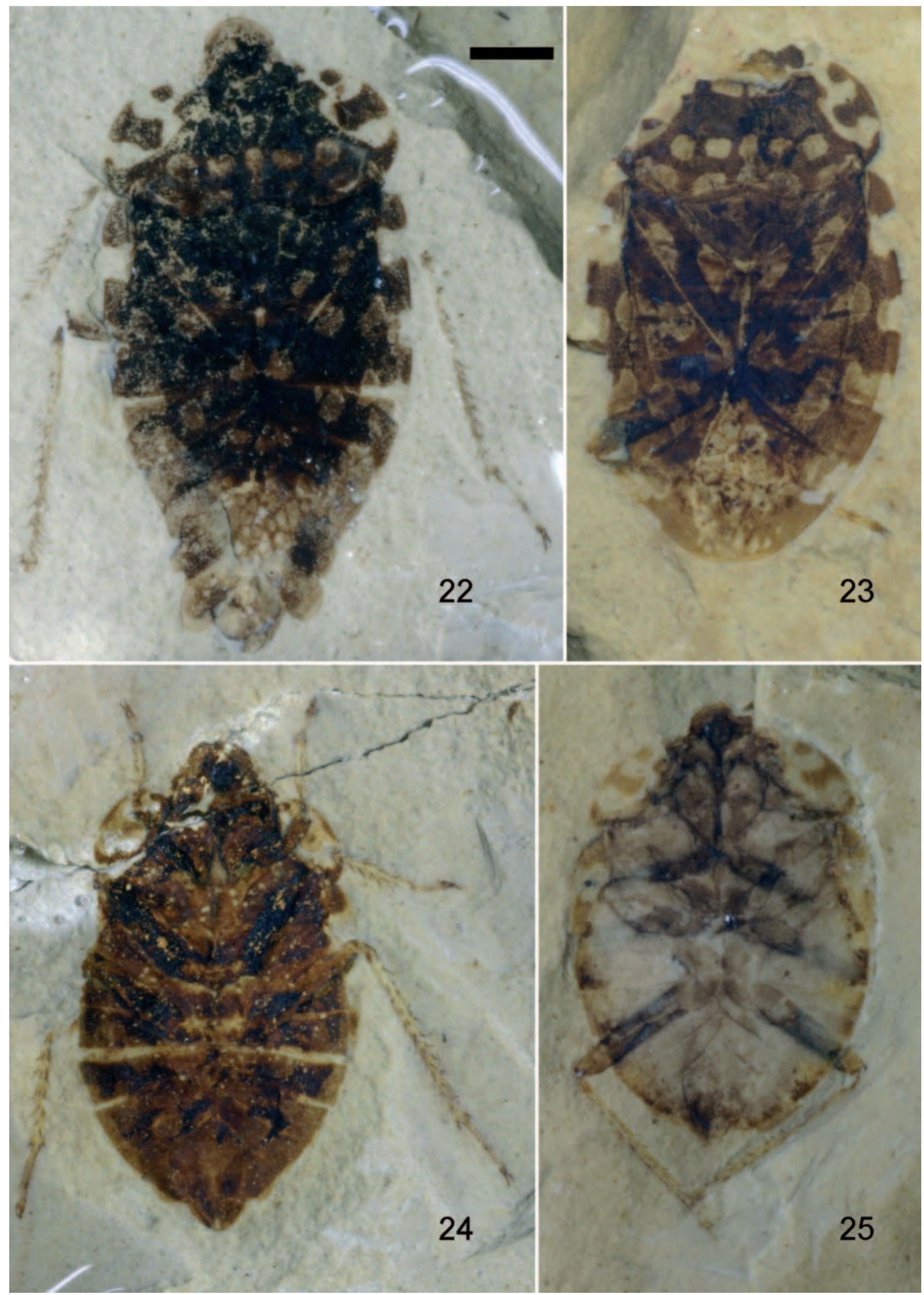

Figs 22-25. Pristinochterus zhangi gen. et sp. n., photograph. $22-\widehat{\delta}$, CNU-HE-LB2006317; 23 - $\widehat{\delta}$, CNU-HE-LB2006310; 24 १, CNU-HE-LB2006305; 25 - §, CNU-HE-LB2006309. Scale: 2 mm. 


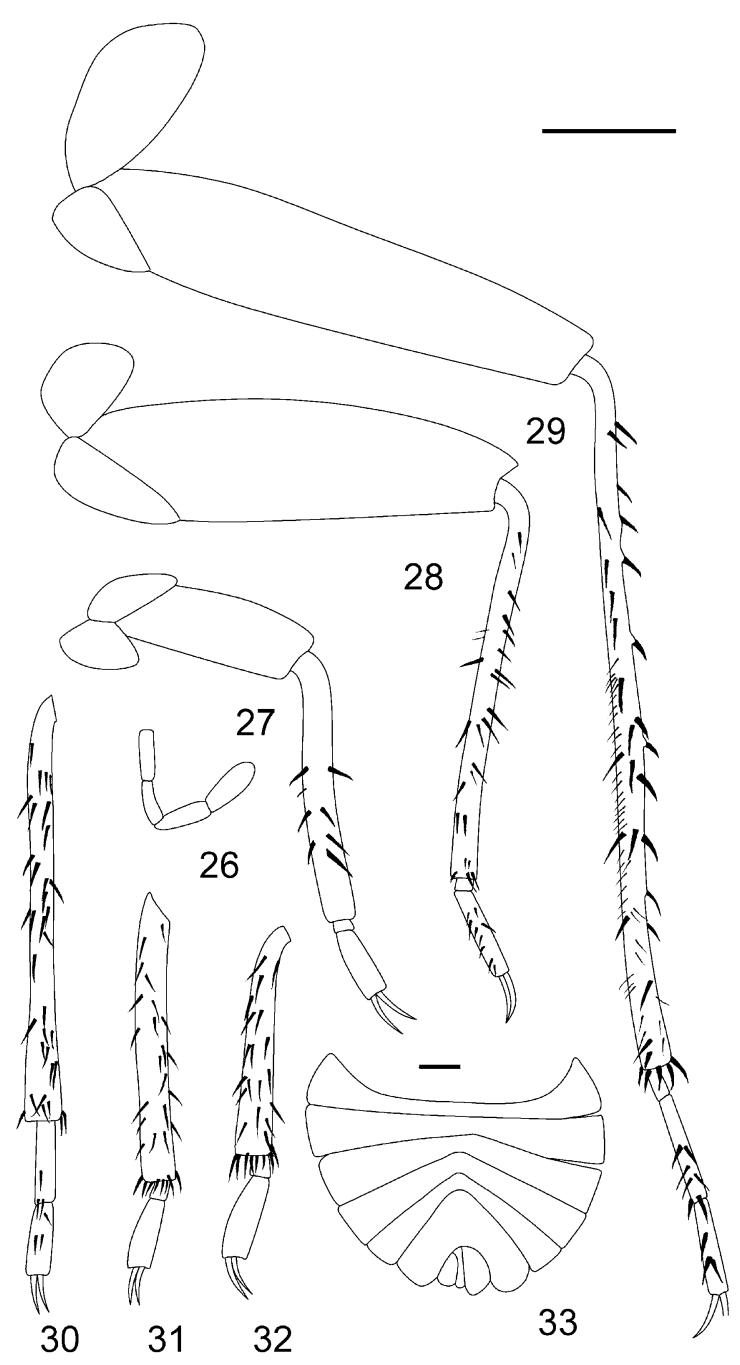

Figs 26-33. Pristinochterus zhangi gen. et sp. n., outline. $26-$ antenna, CNU-HE-LB2006302; 27-29 - legs of adults: 27 fore leg, CNU-HE-LB2006305, 28 - mid leg, CNU-HELB2006302, 29 - hind leg, CNU-HE-LB2006301; 30-32 - legs of nymphs, CNU-HE-LB2006316: 30 - fore leg, 31 - mid leg, 32 - hind leg; 33 - abdomen of male. Scale: $1 \mathrm{~mm}$.

1901 (and also of the aquatic and semiaquatic Trochalopoda). Trans. Am. Entomol. Soc. 32: 117-156.

Kormilev N. 1971: Ochteridae from the Oriental and Australian Regions (Hemiptera-Heteroptera). Pacific Ins. 13: 429-444.

Latreille P.A. 1810: Considérations générales sur l'Ordre naturel des animaux. F. Schoell, Paris, $444 \mathrm{pp}$.

Li P.X., Cheng Z.W. \& PAn Q.Q. 2001: The horizon and age of the Confuciusornis in Beipiao, western Liaoning. Acta Geol. Sin. 75: 1-13 [in Chinese, English abstract].

Liu J.Y., Ren D., Gao C.L., Cheng X.D., Li N.N. \& Liu Z.L. 2004: Discovery of hemeroscopid dragonfly from Jiufotang Formation in western Liaoning and its geological implications. Global Geol. 23: 209-219 [in Chinese, English abstract].

PANG Q.Q., Li P.X., Tian S.G. \& LiU Y.Q. 2002: Discovery of ostracods in the Dabeigou and Dadianzi Formations at Zhangjiagou, Luanping County, northern Hebei Province of China and new progress in the biostratigraphic boundary study. Geol. Bull. China 21: 329-336 [in Chinese, English abstract].
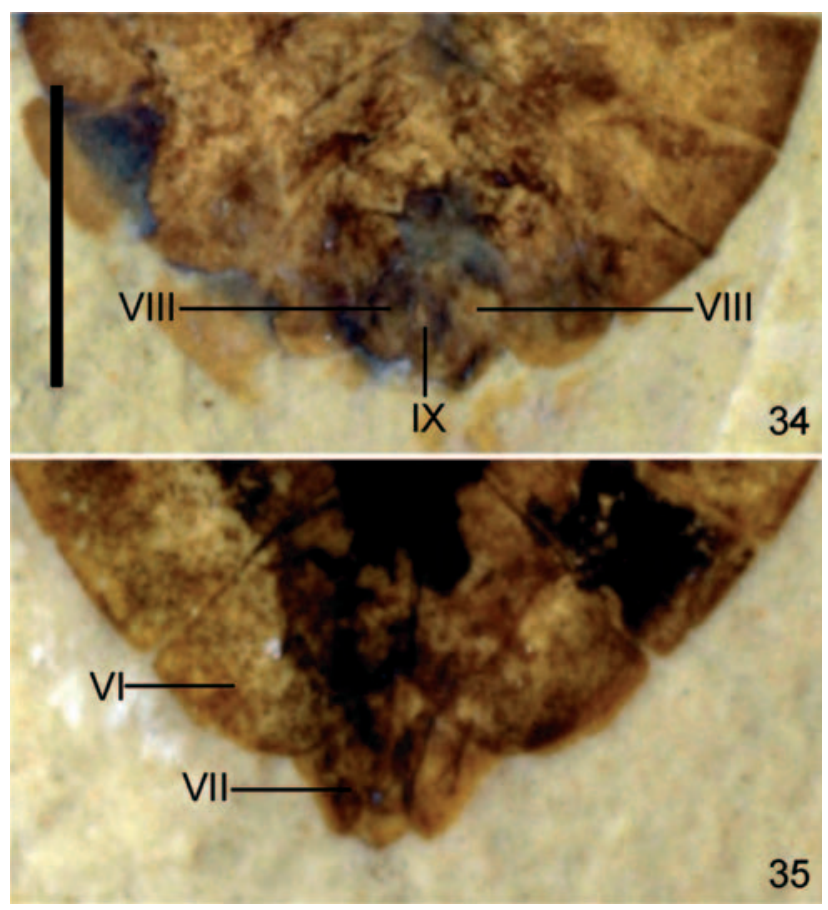

Figs 34-35. Pristinochterus zhangi gen. et sp. n., photograph. 34 - abdomen of male; 35 - abdomen of female. Scale: $2 \mathrm{~mm}$.

Popov Yu.A. 1968: True bugs of the Jurassic Karatau fauna (Heteroptera). In: Jurassic Insects of Karatau. Nauka, Acad. Sci. USSR, Section of General Biology, Moscow, pp. 99-113 [in Russian].

Popov Yu.A., Dolling W.R. \& Whalley P.E.S. 1994: British Upper Triassic and Lower Jurassic Heteroptera and Coleorrhyncha (Insecta: Hemiptera). Genus 5: 307-347.

Ren D., Guo Z.G., Lu L.W., Ji S.A., TANG F., Jin Y.G., Fang X.S. \& JI Q. 1997: A further contribution to the knowledge of the Upper Jurassic Yixian Formation in Western Liaoning. Geol. Rev. 43: 449-459 [in Chinese, English abstract].

Ren D., Gao K.Q., Guo Z.G., Ji S.A., Tan J.J. \& Song Z. 2002: Stratigraphic division of the Jurassic in the Daohugou Area, Ningcheng, Inner Mongolia. Geol. Bull. China 21: 584-591.

Ren D., LiU J.Y. \& Cheng X.D. 2003: A new hemeroscopid dragonfly from the Lower Cretaceous of Northeast China (Odonata: Hemeroscopidae). Acta Entomol. Sin. 46: 622-628.

Schun R.T. \& Slater J.A. 1995: True Bugs of the World (Hemiptera: Heteroptera). Classification and Natural History. Cornell University Press, Ithaca, NY, pp. 107-119.

Shcherbakov D.E. \& Popov Yu.A. 2002: 2.2.1.2.5. Superorder Cimicidea Laicharting, 1781. Order Hemiptera Linné, 1758. The bugs, cicadas, plantlice, scale insects, etc. In Rasnitsyn A.P. \& Quicke D.L.J. (eds): History of Insects. Kluwer Academic Publishers, Dordrecht, pp. 143-157.

Sun G., Dilcher D.L., Zheng S.L. \& Zhou Z.K. 1998: In search of the first flower: A Jurassic angiosperm, Archaefructus, from Northeast China. Science 282: 1692-1695.

Swisher C.C., Wang Y.Q., Wang X.L., Xu X. \& Wang Y. 1999: Cretaceous age for the feathered dinosaurs of Liaoning, China. Nature 400: 58-61.

Tao M.H., Wang K.F., Zhi C.Y. \& CUi J.F. 2003: Spore-pollen assemblages and stratigraphy of Cretaceous in Chifeng Basin Inner Mongolia. J. Tongji Univ. 31: 1034-1038.

Wang W.L, Zhang L.J., Zheng S.L., Zheng Y.J., Zhang H., Li Z.T. \& YANG F.L. 2004: A new study on the stratotype and biostratigraphy of the Yixian stage in Yixian-Beipiao Region, 
Liaoning-establishment and study of stratotypes of the Yixian Stage. Acta Geol. Sin. 78: 433-447.

Wang W.L, Zhang L.J., Zheng S.L., Ren D., Zheng Y.J., Ding Q.H., Zhang H., Li Z.T. \& YANG F.L. 2005: The age of the Yixian Stage and the boundary of Jurassic-Cretaceous-the establishment and study of stratotypes of the Yixian stages. Geol. Rev. 51: 234-242 [in Chinese, English abstract].

WANG X.L. \& ZHou Z.H. 2003: A new pterosaur (Pterodactyloidea, Tapejaridae) from the Early Cretaceous Jiufotang Formation of western Liaoning, China and its implications for biostratigraphy. Chinese Sci. Bull. 48: 16-23.

WANG Y. 2004: Taxonomy and stratigraphy of late Mesozoic anurans and urodeles from China. Acta Geol. Sin. (English ed.) 78: $1169-1178$.
Zheng L.Y. 1999: Class Insecta: Order Hemiptera: Suborder Heteroptera (= Order Hemiptera s. str.). In Zheng L.Y. \& Gui H. (eds): Insect Classification. Naniing Normal University Press, Nanjing, pp. 442-520 [in Chinese].

Zheng S.L., Zheng Y.J. \& XING D.H. 2003: Characteristics, age and climate of Late Jurassic Yixian flora from western Liaoning. J. Stratigraphy 27: 233-241 [in Chinese, English abstract].

Zhou Z.H., Barrett P.M. \& Hilton J. 2003: An exceptionally preserved lower Cretaceous ecosystem. Nature 421: 807-814.

Received October 11, 2006; revised and accepted May 10, 2007 